\title{
Campylobacter pylori in a sample of Finnish population: relations to morphology and functions of the gastric mucosa
}

\author{
M SIURALA, P SIPPONEN, AND M KEKKI \\ From the Second Department of Medicine, University of Helsinki, Helsinki, Finland and Jorvi Hospital, \\ Espoo, Finland
}

SUMMARY The occurrence of Campylobacter pylori (CP) was examined in 179 subjects representing a sample collected from the population of South Finland. In a normal antral and body mucosa $\mathrm{CP}$ was present in $5 \%$ and $11 \%$ and in superficial gastritis (SG) in $71 \%$ and $91 \%$ of subjects, respectively. In atrophic gastritis (AG) of antrum and body the prevalence of $\mathrm{CP}$ decreased significantly with an increasing degree of atrophy, so that $\mathrm{CP}$ was not found in severe body AG. Different combinations of antral and body gastritis revealed a characteristic pattern. Campylobacter pylori was lacking when antral and body mucosa were normal, but was present in $41 \%$ when normal mucosa was associated with gastritis in the opposite area. In SG affecting diffusely antrum and body, the bacterium was present in every case, but when SG was associated with AG in the opposite area it was lacking in $29 \%$ of the subjects. When SG affecting both areas was compared with SG accompanied by different degrees of AG in the body, there was a highly significant decrease of the prevalence of $\mathrm{CP}$ in antrum and body along with an increasing degree of AG in the body. This decrease showed a highly significant positive correlation with the acid output. On the whole, acid output correlated well with the occurrence of $\mathrm{CP}$ in both antrum and body. Thus the prevalence of CP was $10 \%$ in achlorhydria and rose up to $100 \%$ in cases with acid output above $30 \mathrm{mmol} / \mathrm{h}$. The presence of CP did not correlate with signs of acute inflammation, but correlated significantly with those of chronic inflammation. No correlation was found in the antrum and a significant negative one in the body, between CP infestation and the extension of intestinal metaplasia. It is concluded that increased $\mathrm{pH}$ of gastric contents and mucus secreted by intestinalised glands may create unfavourable conditions for survival of the bacteria and might explain the decrease in the prevalence of $\mathrm{CP}$ in the more severe degrees of $\mathrm{AG}$. The present results, however, give no definite answer to the question of the pathogenic significance of $\mathrm{CP}$ in the development of chronic gastritis.

Campylobacter pylori $(\mathrm{CP})$ has been recently implicated in the aetiology of chronic gastritis. ${ }^{1-11}$ These studies are as a rule based upon data obtained from outpatient series, however, which consist mainly of patients with upper abdominal complaints caused by organic or functional alterations of the foregut. To avoid biases, we have studied the occur-

Address for correspondence: Dr Pentti Sipponen, Department of Pathology, Jorvi Hospital, SF-(12740 Espoo. Finland.

Received for publication 12 February 1988. rence of $\mathrm{CP}$ and its relations to different forms and degrees of chronic gastritis in a sample representing the population of South Finland, paying attention to the occurrence of $\mathrm{CP}$ in different phenotypes of antrofundal gastritis, and to the degree of inflammatory reaction and acid secreting capacity of the mucosa.

Methods

SUBJECTS

The series were collected from a South Finnish 909 
population and represent families consisting of first degree relatives of probands computer matched for gastric carcinoma patients. ${ }^{12}$ The studies were performed at the Gastroenterological Unit, Second Department of Medicine, Meilahti Hospital, Helsinki.

The original series consisted, probands included, of 454 subjects. Since the collection of the series, however, the specimens have been cut several times for new stainings. For this reason satisfactory specimens for the staining of $\mathrm{CP}$ were only available in 179 subjects, which accordingly formed the series proper (Table 1).

Three of the 179 subjects suffered from duodenal ulcer and one from gastric ulcer, 15 had hiatal hernia, two prepyloric erosions, four hyperplastic polyps, and five gall bladder disease. Most of the present subjects $(87 \%)$ were symptom free with regard to upper abdominal complaints.

The distribution of the present cases with regard to morphology of the gastric mucosa, various gastroduodenal diseases, complaints, age, and sex distributions was roughly similar to that of the original series. The mean age and the male/female ratio in the present and the original series were 53 and 40 years and $1 \cdot 1$ and $1 \cdot 0$, respectively. The occurrence of upper abdominal complaints was similar, $13 \%$ and $14 \%$, respectively. The prevalence of all gastritis cases was somewhat, but not strikingly, higher in the present series - for example, in the antrum $74 \%$ as compared with $68 \%$ in the original series.

All 179 subjects were examined by gastroduodenoscopy and biopsy specimens were obtained from antral (more than four specimens) and from body (more than six specimens) mucosa. On an average, 11.2 specimens were available from each subject. The specimens were fixed overnight in neutral buffered formalin, embedded in paraffin and stained by a modified Giemsa method. ${ }^{13}$ Table 1 shows that in 22 cases the presence of $\mathrm{CP}$ could be estimated in only one area of the stomach (antrum or body) because of inadequate quality of the specimens. Accordingly, data on $\mathrm{CP}$ were available from antrum and body for 157 subjects.

The pentagastrin test was done as described earlier ${ }^{12}$ in all cases. Because of the limited number of cases, men and women were not treated separately.

\section{Table 1 Examinations carried out}

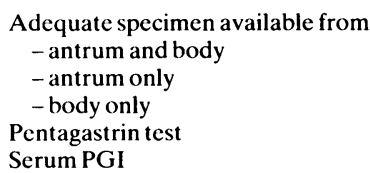

Table 2 Occurrence of CP in antrum and body in the whole series

\begin{tabular}{|c|c|c|c|c|}
\hline \multirow[b]{2}{*}{ Status of the mucosa } & \multicolumn{2}{|l|}{ Antrum } & \multicolumn{2}{|l|}{ Body } \\
\hline & $\begin{array}{l}\text { Number and } \\
\text { prevalence } \\
\text { of }(P \text { - } \\
\text { positive } \\
\text { cases }\end{array}$ & $\begin{array}{l}\text { Cases } \\
(n)\end{array}$ & $\begin{array}{l}\text { Number and } \\
\text { prevalence } \\
\text { of } C P \text { - } \\
\text { positive } \\
\text { cases }\end{array}$ & $\begin{array}{l}\text { Cases } \\
\text { (n) }\end{array}$ \\
\hline Normal & $2(5 \%)$ & 42 & $4(11 \%)$ & 36 \\
\hline Superficial gastritis & $34(71 \%)$ & 48 & $63(91 \%)$ & 69 \\
\hline Light atrophic gastritis & $37(65 \%)$ & 57 & $15(60 \%)$ & 25 \\
\hline Moderate atrophic gastritis & $9(41 \%)$ & 22 & $6(22 \%)$ & 27 \\
\hline Severe atrophic gastritis & $2(100 \%)$ & 2 & $0(0 \%)$ & 8 \\
\hline Cases (n) & $84(49 \%)$ & 171 & $88(53 \%)$ & 165 \\
\hline
\end{tabular}

STATISTICAL ANALYSIS

$\chi^{2}$ test and Student's $t$ test were used in statistical calculations. Deviations were expressed as standard deviation (SD). To test simultaneously the relationship of CP infestation to the degree of gastritis and the severity of acute and chronic inflammation we used a $\log$ linear model in three way contingency table. ${ }^{14}$

\section{DEFINITIONS}

Antral and body gastritis was scored using the loss of normal elements as the main principle of classification as follows: normal mucosa (NM): no loss of glands. This grading closely resembles that of (SG): no loss of glands but round cell infiltration; light, moderate, and severe atrophic gastritis (LAG, MAG, SAG): light, moderate, and severe loss of glands. This grading resembles closely that of Schindler ${ }^{15}$ and $\mathrm{Rao}$ et $a l^{16}$ and is largely similar to those of many others (see 17). In the body the grading shows an excellent correlation with different functional parameters. ${ }^{17}$

The amount of round cell infiltration was roughly graded as absent or slight, moderate, and severe. Acute inflammation was not graded because of its spotty occurrence and only distinct changes were taken into account - that is, the more confluent granulocyte infiltrations up to formation of crypt abscesses with or without micro-erosions.

Intestinal metaplasia was graded as slight when only a few metaplastic tubules were present, as moderate when a larger number of tubuli were seen, and as severe when most tubuli were of intestinal type.

\section{Results}

CAMPYLOBACTER PYLORI IN DIFFERENT CONDITIONS OF ANTRAL AND BODY MUCOSA In Table 2 the total number of adequate antral and body specimens approached 171 and 165, respect- 
Table 3 Occurrence of CP in different phenotypes of gastric mucosa

\begin{tabular}{|c|c|c|c|c|}
\hline \multirow[b]{2}{*}{ Phenotype } & \multicolumn{4}{|c|}{$\begin{array}{l}\text { Campylobacteria in antrum } \\
\text { and/orbody }\end{array}$} \\
\hline & $\begin{array}{l}\text { Present } \\
\text { in both } \\
\text { areas }\end{array}$ & $\begin{array}{l}\text { Presen } \\
\text { in one } \\
\text { area }\end{array}$ & $\begin{array}{l}\text { Absent } \\
\text { in both } \\
\text { areas }\end{array}$ & Cases \\
\hline Normal mucosa in antrum and body & () & 0 & 26 & 26 \\
\hline $\begin{array}{l}\text { Normal mucosa in one area, gastritis } \\
\text { in the opposite }\end{array}$ & 5 & 2 & 10 & 17 \\
\hline $\begin{array}{l}\text { Superficial gastritis in antrum and } \\
\text { body }\end{array}$ & 27 & 3 & 0 & 30 \\
\hline $\begin{array}{l}\text { Superficial gastritis in one area, } \\
\text { atrophic in the opposite }\end{array}$ & 25 & 11 & 15 & 51 \\
\hline $\begin{array}{l}\text { Atrophic gastritis in antrum and } \\
\text { body }\end{array}$ & 11 & 10 & 12 & 33 \\
\hline Cases (n) & 68 & 26 & 63 & 157 \\
\hline
\end{tabular}

ively, because, as shown in Table 1, in some cases the presence of CP could not be established in one of the areas. Table 2 shows that CP was rarely seen in normal mucosa and when present it appeared together with gastritis in the opposite area (Table 3). It was found, however, in most cases of superficial gastritis (SG) in antrum and body. The cases of SG that lacked the bacteria were usually accompanied by atrophic gastritis (AG) in the opposite area (Table $3)$. In $A G$ the prevalences of $C P$ decreased concomitantly with an increasing degree of AG. The only exceptions were cases of severe antral AG (SAG), but there were only two such cases in the present series. The decrease in the prevalence of $\mathrm{CP}$ from SG to moderate AG (MAG) was statistically significant: in the antrum at $1 \%$ and in the body at $0 \cdot 1 \%$ level.

The prevalence of CP increased slightly with age, but the increase was not statistically significant. Sex distribution of $\mathrm{CP}$ positive and negative cases revealed no significant differences.

No correlation could be shown between the occurrence of $\mathrm{CP}$ and upper abdominal complaints. Such complaints were present in $15 \%$ of the $\mathrm{CP}$ positive and $12 \%$ of the $\mathrm{CP}$ negative cases. This difference was not statistically significant.

\section{OCCURRENCE OF CAMPYLOBACTER PYLORI IN} DIFFERENT PHENOTYPES OF GASTRITIS

The different combinations of antral and body gastritis are designated phenotypes according to our earlier studies, ${ }^{17}$ as well as according to the studies of others, ${ }^{18}$ suggesting that genetic factors are involved at the onset of gastritis as well as in the development of later stages of gastritis.

Table 3 shows that the presence of $\mathrm{CP}$ in one area was associated with its absence in the opposite area in
Table 4 Occurrence of $C P$ in phenotypes $A, B$, and $A B$

\begin{tabular}{lcclc}
\hline & \multicolumn{2}{l}{ Campylobacter pylori } & \\
\cline { 2 - 4 } & $\begin{array}{l}\text { Present in } \\
\text { both areas }\end{array}$ & $\begin{array}{l}\text { Present in } \\
\text { one area }\end{array}$ & $\begin{array}{l}\text { Absent in } \\
\text { both areas }\end{array}$ & $\begin{array}{l}\text { Cases } \\
(n)\end{array}$ \\
\hline Phenotype A & 0 & 0 & 8 & 8 \\
Phenotype B & 9 & 7 & 1 & 17 \\
Phenotype AB & 11 & 12 & 9 & 32 \\
\hline
\end{tabular}

$17 \%$ of the cases. Such dissimilar behaviour of the two areas was particularly evident when one or both areas were affected with AG. Only a completely normal gastric mucosa displayed a uniform behaviour: in all cases $\mathrm{CP}$ was lacking in antrum and body. If normal mucosa in one area was associated with gastritis in the opposite one, however, the occurrence of $\mathrm{CP}$ was different: about $40 \%$ of the cases $\mathrm{CP}$ was present in one or both stomach areas. Similarly, when affecting the whole stomach SG showed a distinctly more uniform behaviour than when associated with AG in the opposite area. The differences between diffuse SG and SG affecting only one area were, with regard to complete absence of $\mathrm{CP}$, statistically highly significant $(\mathrm{p}<0 \cdot 001)$. The presence of $C P$ in both areas decreased further, as shown by Table 3 , in cases with AG affecting the whole gastric mucosa.

The diverging behaviour of the different phenotypes of gastritis is further illustrated by Table 4 , which shows the occurrence of $\mathrm{CP}$ in advanced stages of $A G$ representing the more specific phenotypes $A$ (severe AG in the body) ${ }^{19} \mathrm{~B}$ (AG in antrum but no AG in the body), ${ }^{19}$ and $A B$ (AG in both antrum and body). ${ }^{20}$ In phenotype A CP was lacking in both areas in all cases, but in phenotype B CP was present with one exception in both areas or in either of them. The difference between phenotypes A and B was statistically highly significant $(\mathrm{p}<0 \cdot 001)$.

Because of the diverging behaviour of the antral

Table 5 Prevalence of CP in different combinations of antral and body gastritis

\begin{tabular}{|c|c|c|c|c|c|c|}
\hline & $\begin{array}{l}\text { Pheno- } \\
\text { type }\end{array}$ & $\begin{array}{r}\text { Preval- } \\
\text { - ence of } \\
\text { CP }(\%)\end{array}$ & $\begin{array}{l}\text { Pheno- } \\
\text { type }\end{array}$ & $\begin{array}{r}\text { Preval- } \\
\text { - ence of } \\
C P(\%)\end{array}$ & $\begin{array}{l}\text { Pheno- } \\
\text { type }\end{array}$ & $\begin{array}{r}\text { Preval- } \\
\text { - ence of } \\
C P(\%)\end{array}$ \\
\hline Antrum & SG/ & 89 & $\mathrm{SG} /$ & 33 & $\mathrm{SG} /$ & 11 \\
\hline Body & SG & 92 & LAG & 33 & MAG & 14 \\
\hline $\begin{array}{l}\text { Acid output, } \\
\mathrm{mmol} / \mathrm{h}\end{array}$ & $31 \cdot 6$ & & $13 \cdot 3$ & & $1 \cdot 1$ & \\
\hline Antrum & SG/ & 89 & LAG/ & 74 & MAG/ & 50 \\
\hline Body & SG & 92 & SG & 88 & SG & 92 \\
\hline $\begin{array}{l}\text { Acid output, } \\
\mathrm{mmol} / \mathrm{h}\end{array}$ & 31.9 & & $24 \cdot 3$ & & $22 \cdot 3$ & \\
\hline
\end{tabular}


and body mucosae and the different phenotypes, the behaviour of the various combinations of SG treating separately the antral and body mucosa has been evaluated in Table 5 . Table 5 shows that the prevalences of CP in antrum and body decrease with increasing degree of body gastritis. Thus, in addition to the decrease of $\mathrm{CP}$ positivity in the more severely affected body with an increasing degree of gastritis, there occurs a similar dramatic and highly significant $(p<0.001)$ decrease in the antrum, which remains at the stage of SG. When on the other hand, the status of the body (Table 5) remains at the stage of SG and the antrum shows different degrees of gastritis, the more affected side (antrum) shows decrease in the prevalences of $\mathrm{CP}$, which, however, is rather slight and significant at a $5 \%$ level only. No decrease is seen in the body, which keeps at the stage of SG. Table 5 also shows the excellent correlation between the prevalences of $\mathrm{CP}$ and the results of the pentagastrin test.

\section{CAMPYLOBACTER PYLORI IN DIFFERENT KINDS} AND DEGREES OF ROUND CELL INFILTRATION

\section{Signs of chronic inflammation}

In superficial gastritis, round cell infiltration was confined, according to definition, to the more superficial layers of the lamina propria. For this reason we have treated it separately from $A G$, in which the distribution of the cells was more diffuse. In SG the prevalence of $\mathrm{CP}$-positive cases was rather similar in the different degrees of round cell infiltration. Thus, in slight accumulation of round cells in the body mucosa the prevalence of $\mathrm{CP}$ was $91 \%$, in moderate $84 \%$, and in severe $100 \%$.

In AG (Table 6) there was a slight increase of the prevalences of $\mathrm{CP}$ along with increasing degrees of round cell infiltration but the differences were not statistically significant. There were no significant differences with regard to occurrence of lymph follicles in the lamina propria between the CP positive and negative cases, either.

Table 6 Occurrence of CP and degree of chronic inflammation in cases of atrophic gastritis

\begin{tabular}{|c|c|c|c|c|}
\hline \multirow[b]{2}{*}{ Chronic inflammation } & \multicolumn{2}{|l|}{ Antrum } & \multicolumn{2}{|l|}{ Body } \\
\hline & $\begin{array}{l}\text { Number and } \\
\text { prevalence } \\
\text { (\%) of } C P \text { - } \\
\text { positive } \\
\text { cases }\end{array}$ & $\begin{array}{l}\text { Cases } \\
(n)\end{array}$ & $\begin{array}{l}\text { Numberand } \\
\text { prevalence } \\
\text { (\%) of } C P \text { - } \\
\text { positive } \\
\text { cases }\end{array}$ & $\begin{array}{l}\text { Cases } \\
(n)\end{array}$ \\
\hline Slight or absent & $6(38 \%)$ & 16 & $1(17 \%)$ & 6 \\
\hline Moderate & $11(55 \%)$ & 20 & $6(40 \%)$ & 15 \\
\hline Severe & $29(62 \%)$ & 47 & $16(42 \%)$ & 38 \\
\hline
\end{tabular}

Table 7 Occurrence of CP and the extent of intestinal metaplasia in cases of atrophic gastritis

\begin{tabular}{|c|c|c|c|c|}
\hline \multirow[b]{2}{*}{$\begin{array}{l}\text { Extent of intestinal } \\
\text { metaplasia }\end{array}$} & \multicolumn{2}{|l|}{ Antrum } & \multicolumn{2}{|l|}{ Body } \\
\hline & $\begin{array}{l}\text { Numberand } \\
\text { prevalence } \\
(\%) \text { of } C P \text { - } \\
\text { positive } \\
\text { cases }\end{array}$ & $\begin{array}{l}\text { Cases } \\
\text { (n) }\end{array}$ & $\begin{array}{l}\text { Number and } \\
\text { prevalence } \\
\text { (\%) of CP- } \\
\text { positive } \\
\text { cases }\end{array}$ & $\begin{array}{l}\text { Cases } \\
\text { (n) }\end{array}$ \\
\hline Slight or absent & $24(53 \%)$ & 45 & $16(47 \%)$ & 34 \\
\hline Moderate & $10(59 \%)$ & 17 & $7(58 \%)$ & 12 \\
\hline Severe & $11(52 \%)$ & 21 & $1(8 \%)$ & 13 \\
\hline
\end{tabular}

Signs of acute inflammation

An insignificant correlation was found between signs of acute inflammation and the presence of CP. Acute signs, such as distinct aggregation of granulocytes with or without micro-erosions or crypt abscesses, were found in $54 \%$ of the CP positive and $34 \%$ of the $\mathrm{CP}$ negative cases. The difference was not statistically significant.

The use of a three way contingency table and a logistic model showed a significant positive correlation with signs of chronic inflammation but not with signs of acute inflammation and the degree of chronic gastritis.

RELATIONSHIP OF INTESTINAL METAPLASIA TO THE OCCURRENCE OF CAMPYLOBACTER PYLORI Table 7 shows that in cases of AG there is no positive correlation between the presence of $\mathrm{CP}$ and the extension of intestinal metaplasia in antrum and a significantly $(p<0.01)$ negative correlation in the body. In fact, in a CP infested mucosa the bacteria were only occasionally seen in the near vicinity of intestinal tubuli.

RELATIONSHIP OF FUNCTIONAL PARAMETERS TO THE OCCURRENCE OF CAMPYLOBACTER PYLORI Table 8 shows that the occurrence of $C P$ is significantly associated with acid output as measured by pentagastrin test and expressed in terms of $\mathrm{mmol} / \mathrm{h}$. The mean acid output was highly significantly higher $(\mathrm{p}<0.001)$ in subjects infested by CP than in those who were free of the bacteria. Likewise, the prevalence of achlorhydria and of acid values below 10 $\mathrm{mmol} / \mathrm{h}$ was significantly higher $(\mathrm{p}<0.001)$ in subjects without $\mathrm{CP}$ than in those with bacteria.

From Table 5 it appears that the acid output closely follows the behaviour of the prevalences of $\mathrm{CP}$ in the different phenotypes of gastritis. When SG in the antrum was associated with different degrees of gastritis in the body, there was in both antrum and body a highly significant $(p<0 \cdot 001)$ decrease of the prevalences of $\mathrm{CP}$, along with a highly significant 
Table 8 Occurrence of CP and acid output in cases of atrophic gastritis

\begin{tabular}{|c|c|c|c|c|}
\hline \multirow[b]{2}{*}{ Acid output mmol/h } & \multicolumn{2}{|l|}{ Antral $A G$} & \multicolumn{2}{|l|}{$\operatorname{Body} A G$} \\
\hline & $\begin{array}{l}\text { Numberand } \\
\text { prevalence } \\
(\%) \text { of } C P \text { - } \\
\text { positive } \\
\text { cases }\end{array}$ & $\begin{array}{l}\text { Cases } \\
\text { (n) }\end{array}$ & $\begin{array}{l}\text { Numberand } \\
\text { prevalence } \\
\text { (\%) of } C P \text { - } \\
\text { positive } \\
\text { cases }\end{array}$ & $\begin{array}{l}\text { Cases } \\
\text { (n) }\end{array}$ \\
\hline Achlorhydria & $1(10 \%)$ & 10 & $4(15 \%)$ & 27 \\
\hline$\leq 10$ & $8(53 \%)$ & 15 & $7(39 \%)$ & 18 \\
\hline $11-30$ & $32(65 \%)$ & 49 & $10(83 \%)$ & 12 \\
\hline$\geq 30$ & $8(89 \%)$ & 9 & $2(100 \%)$ & 2 \\
\hline Mean acid output in & Antral $A G$ & & Body $A G$ & \\
\hline CP present & $20 \cdot 9(11 \cdot 9)$ & & $21 \cdot 4(11 \cdot 5)$ & \\
\hline CPabsent & $7 \cdot 8(8 \cdot 6)$ & & $4 \cdot 7(8 \cdot 6)$ & \\
\hline
\end{tabular}

Values of acid output are expressed as mean (SD).

( $p<0 \cdot 001)$ decrease of acid output, which followed the increase of AG in the body. On the other hand, when SG in the body was associated with different degrees of gastritis in the antrum, the prevalences of $\mathrm{CP}$ remained high in the body but decreased slightly in the antrum concomitantly with a slight but significant $(p<0.01)$ decrease of acid output (from 32 to 22 $\mathrm{mmol} / \mathrm{h})$. The acid output, however, still remained within limits that could be considered normal for men and women. The occurrence of CP correlated well, as expected, with fasting serum pepsinogen I concentrations (determined by M I Samloff, LA, Ca). Thus the mean SPG I was higher and the number of cases with low levels was high significantly lower in subjects with $\mathrm{CP}$ than in those who were free of the bacteria.

\section{Discussion}

The present series are selected from a sample considered representative of the population of South Finland, depending upon the availability of specimens for new cutting and staining. It is therefore possible that the present results reflect the behaviour of an over 15 year old Finnish population at large. The occurrence of $\mathrm{CP}$ in the present material was largely similar to that reported in the literature. ${ }^{56}{ }^{1021-27}$ Thus most cases with superficial gastritis (SG) revealed the presence of the bacterium, while in a normal mucosa it was as a rule lacking. In addition, with an increasing degree of AG there was a significant decrease of prevalences of $\mathrm{CP}$, particularly in the body, where the prevalence of CP dropped from $91 \%$ in SG to $0 \%$ in severe atrophic gastritis (AG). A decreased occurrence of $\mathrm{CP}$ in the more severe degrees of $\mathrm{AG}$ has also been noted by other authors. ${ }^{72.25}$ On the whole the prevalences of $\mathrm{CP}$ were very high in the present series and may have been even higher if bacterial cultures had been done but these were not because of the retrospective nature of the study.

When the occurrence of $\mathrm{CP}$ was considered simultaneously in antrum and body it appeared that the behaviour of one area of the stomach reflected to some degree the behaviour of the opposite area. Thus SG in antrum associated with SG in the body showed a high prevalence of CP in both areas: about $90 \%$. On the other hand, antral SG associated with various degree of $A G$ in the body revealed a significant decrease of $\mathrm{CP}$ positivity both in antrum and body with increasing severity of $A G$ in the body. These findings can hardly be attributed to changing morphological conditions because there was a drop of $\mathrm{CP}$ positivity in the antrum where the status remained unchanged at the level of SG. Likewise, in severe AG of the body (phenotype $\mathrm{A})^{1719} \mathrm{CP}$ was lacking, not only in the body, but also in antrum irrespective of the morphology of the antral mucosa. One the other hand, the acid output showed a highly significant decrease and the prevalences of hypochlorhydria and achlorhydria a highly significant increase concomitantly with a decrease of $\mathrm{CP}$ positivity and an increase of the degree of AG in the body.

We believe that the decrease in acid secretion creates an unfavourable milieu for the growth of $\mathrm{CP}$, as also claimed by other authors. ${ }^{26}{ }^{28} \mathrm{We}$ are well aware, however, of the studies that suggest $\mathrm{CP}$ is resistent to achlorhydria induced by short term treatment with $\mathrm{H}_{2}$ blockers. ${ }^{24}{ }^{30}$

The increased $\mathrm{pH}$ of gastric contents is hardly the sole explanation for the decrease of $\mathrm{CP}$ positivity with increasing degree of gastritis. It is possible that intestinalisation of the gastric mucosa which follows the development of AG, may play some part by producing a mucus which changes the growth milieu for the CP. Thus CP has not been found in the small intestinal mucosa and is rarely seen in an intestinalised gastric mucosa. ${ }^{2326}{ }^{261-33}$ In the present study also, we did not find the bacteria within the crypts of intestinal type, and there was in the body a significant negative correlation between the extent of metaplasia and the occurrence of CP. Additional factors involved in the occurrence of $\mathrm{CP}$ might be the immunological defence mechanism and duodenal regurgitation with or without infestation with other bacteria - that is, coliform bacteria, which might effectively compete with the CP.

The two factors possibly involved in the occurrence of $\mathrm{CP}$ in the gastric mucosa - that is, the $\mathrm{pH}$ of the gastric contents and intestinal metaplasia, may explain the variability in the $\mathrm{CP}$ infestation noted in 
different degrees and different phenotypes of chronic gastritis.

An important aspect which still remains unexplained, is the lack of CP in a normal gastric mucosa, in which the acid output is similar to SG and intestinal metaplasia is absent. A simple explanation may be that they have not been exposed to CP infestation. This view is supported by our finding that when normal mucosa in one area is associated with $\mathrm{CP}$ infested gastritis in the opposite side, bacteria were also found in the normal side in a considerable proportion of cases. This explanation might not be sufficient, however, because in the present study a significant proportion of cases (about $20 \%$ ) infested with CP had bacteria only in one part of the stomach. Moreover, Jones $\mathrm{et}_{\mathrm{al}} \mathrm{l}^{3+}$ found no more than expected frequency of $\mathrm{CP}$ in spouses of patients infested with $\mathrm{CP}$.

Another explanation for the lack of $\mathrm{CP}$ in a normal gastric mucosa could be the absence of liability to maintain the bacteria despite an exposure to infection. This lack of liability could be in part genetically determined. We have shown earlier ${ }^{17}$ that genetic factors play a role in the onset and early progression of gastritis. Indeed, they seem to delay the progression of SG up to middle age, when differentiation into the more specific forms, phenotypes $\mathrm{A}, \mathrm{B}$, and $\mathrm{AB},{ }^{17}{ }^{10}{ }^{20}$ takes place.

It seems obvious that the present results do not give a definite answer to the most crucial question as to whether CP is the cause of chronic gastritis or simply a parasite associated with a diseased gastric mucosa. Literature data suggest, however, the existence of an aetiologic relationship. A local and a systemic immunoresponse seems to accompany $\mathrm{CP}$ infestation: a local accumulation of granulocytes, leukopedesis, crypt abscesses and micro erosions have been found in the near vicinity of the bacteria $^{1811}$ and antibodies against the bacterium have been found in the sera of patients with CP infestation. ${ }^{y-1121}$ Moreover, disappearance of the bacteria and signs of acute and chronic inflammation have been reported after antibiotic therapy and treatment with bismuth compounds. ${ }^{27}{ }^{35} 36$ We have also found a significant positive correlation between $\mathrm{CP}$ and signs of chronic inflammation, but were unable to show a correlation between $\mathrm{CP}$ and signs of acute inflammation. We believe that $\mathrm{CP}$ could be one of the factors which act as trigger like mechanisms at the onset of gastritis in persons genetically susceptible to the disease. Further progression of gastritis, however, particularly the development of the more specific forms (phenotypes $\mathrm{A}, \mathrm{B}$, and $\mathrm{AB}$ ) seems independent of the presence of $\mathrm{CP}$, as is shown by the significant decrease of the prevalences of $\mathrm{CP}$ with increasing degree of $\mathrm{AG}$, and its complete absence in the phenotype A.
We could not find in the present study any evidence to support the existence of a pathogenic relationship between $\mathrm{CP}$ and gastric ulcer. Indeed, in the present series active gastric ulcer was found in only one case despite a very high prevalence of CP. Neither did we find any correlation between $\mathrm{CP}$ and upper abdominal symptoms: the present series represent a virtually symptomless population and in the few cases with non-ulcer dyspepsia the prevalence of $\mathrm{CP}$ did not exceed that found in the symptomless people.

The study was supported by grants from Yrjö Jahnsson Foundation, Helsinki, Finland. We wish to express our thanks to Professor I M Samloff for determination of serum pepsinogen I levels.

\section{References}

1 Marshall BJ, Warren JR. Unidentified curved bacilli in the stomach of patients with gastritis and peptic ulceration. Lancet 1984; i: 1311-4.

2 Rollason TP, Stone J, Rhodes JM. Spiral organisms in endoscopic biopsies of the human stomach. J Clin Pathol 1984; 37: 23-6.

3 McNulty CAM, Watson DM. Spiral bacteria of the gastric antrum. Lancet 1984; i: 1068-9.

4 Jones DM, Lessels AM, Eldbridge J. Campylobacter like organisms on the gastric mucosa: culture, histological, and serological studies. J Clin Pathol 1984; 37: 1002-6.

5 Langenberg ML, Tytgat GNJ, Schipper MEI, Rietra PJGM, Zanen HC. Campylobacter like organisms in the stomach of patients and healthy individuals. Lancet 1984 ; i: 1348.

6 Tytgat GNJ, Langenberg ML, Rawus E, Rietra PJGM. Campylobacter-like organisms (CLO) in the human stomach. Gastroenterology 1985; 88: 1620.

7 Price AB, Levi J, Dolby JM, et al. Campylobacter pyloridis in peptic ulcer disease: microbiology, pathology, and scanning electron microscopy. Gut 1985; 26: $1183-8$.

8 Marshall BJ, Armstrong JA, McGechie DB, Glancy RJ. Attempt to fulfill Koch's postulates for phyloric Campylobacter. Med J Aust 1985; 142: 436-9.

9 Rathbone BJ, Wyatt JI, Worsley BW, et al. Systemic and local antibody responses to gastric Campylobacter pyloridis in non-ulcer dyspepsia. Gut 1986; 27: 642-7.

10 von Wulffen AU, Heesemann J, Butzow GH, Loning T, Laufs R. Detection of Campylobacter pyloridis in patients with antrum gastritis and peptic ulcers by culture, complement fixation test, and immunoblot. J Clin Microbiol 1986; 24: 716-20.

11 Wyatt JI, Rathbone BJ, Heatley RV. Local immune response to gastric Campylobacter in non-ulcer dyspepsia. J Clin Pathol 1986; 39: 836-70.

12 Ihamäki T, Varis K, Siurala M. Morphological, functional and immunological state of the gastric mucosa in gastric carcinoma families: comparison with a computer-matched family sample. Scand J Gastroenterol 1979; 14: 801-12. 
13 Grey SF, Wyatt JI, Rathbone BJ. Simplified techniques for identifying gastric Campylobacter pyloridis on tissue sections. J Clin Pathol 1986; 39: 1279-80.

14 Sokal RR, Rohlf JF. Biochemistry. New York: W H Freeman, 1981.

15 Schindler R. Gastritis. New York: Grune \& Stratton, 1947.

16 Rao SS, Krasner N, Thomson TJ. Chronic gastritis - a simple classification. J Pathol 1975; 117: 93-6.

17 Kekki M, Siurala M, Varis K, Sipponen P, Sistonen P, Nevanlinna $\mathbf{H}$. Classification principles and genetics of chronic gastritis. Scand J Gastroenterol 1987; Suppl 141: 22: $1-12$.

18 Bonney GE, Elston RC, Correa P, et al. Genetic etiology of gastric carcinoma: I. Chronic atrophic gastritis. Genet Epidemiol 1986; 3: 213-24.

19 Strickland RG, Mackay IR. A reappraisal of the nature and significance of chronic atrophic gastritis. J Dig Dis 1973; 18: 426-40.

20 Glass GBJ, Pitshumoni CS. Atrophic gastritis. Hum Pathol 1975; 6: 219-50.

21 Booth L, Holdstock G, MacBride H, et al. Clinical importance of Campylobacter pyloridis and associated serum $\mathrm{IgG}$ and $\mathrm{IgA}$ antibody responses in patients undergoing upper gastrointestinal endoscopy. J Clin Pathol 1986; 39: 215-9.

22 Marshall BJ, McGechie DB, Rogers PA, Glancy RJ. Pyloric Campylobacter infection and gastroduodenal disease. Med J Aust 1985; 142: 439-44.

23 O'Connor HJ, Axon ATR, Dixon MF. Campylobacterlike organisms unusual in type A (pernicious anaemia) gastritis. Lancet 1984; ii: 1091.

24 Buck GE, Gourley WK, Lee WK, Subramanyam K, Latimer JM, DiNuzzo AR. Relation of Campylobacter pyloridis to gastritis and peptic ulcer. J Infect Dis 1986; 153: 664-9.

25 Karttunen T, Niemelä S, Lehtola J, Heikkilä J, Mäentausta $O$, Räsänen $O$. Campylobacter-like organisms and gastritis: histopathology, bile reflux, and gastric fluid composition. Scand J Gastroenterol 1987; 22: $478-86$.

26 Sipponen P, Varis K, Cederberg A, et al. Campylobacter pylori is associated with chronic gastritis but not with active peptic ulcer disease. APMIS 1988; 96; 84-8.

27 Goodwin CS, Armstrong JA, Marshall BJ. Campylobacter pyloridis, gastritis, and peptic ulceration. J Clin Pathol 1986; 39: 353-65.

28 Wyatt JI, Rathbone BJ, Dixon MF, Heatley RV. Campylobacter pyloridis and acid induced gastric metaplasia in the pathogenesis of duodenitis. J Clin Pathol 1987; 40: 841-8.

29 Lambert JR, Hansky J, Davidson A, Pinkard K, Stockman K. Campylobacter like organisms (CLO) - in vivo and in vitro susceptibility to antimicrobial and antiulcer therapy. Gastroenterology 1985; 88: 1462.

30 McLean AI, Harrison PTI, Joannides-Demos LL, Byrne AJ, McCarthy P, Dudley FJ. Microbes, peptic ulcer, and relapse rates with different drugs. Lancet 1984; 2: 525-6.

31 Steer HW. Surface morphology of the gastroduodenal mucosa in duodenal ulceration. Gut 1984; 25: 1203-10.

32 Phillips AD, Hine KR, Holmes GKT, Woodings DF. Gastric spiral bacteria. Lancet 1984; ii: 100-1.

33 Lambert JR, Hansky J, Eaves ER, Korman MG, Pinkard K, Medley G. Campylobacter like organisms (CLO) in human stomach. Gastroenterology 1985; 88: 1463.

34 Jones DM, Eldridge J, Whorwell PJ. Antibodies to Campylobacter pyloridis in household contacts of infected patients. Br Med J 1987; 294: 615.

35 Tytgat GNJ, Rauws E, Langenberg W. The role of colloidal bismuth subcitrate in gastric ulcer and gastritis. Scand J Gastroenterol 1986; 21 : 22-9.

36 McNulty CA, Gearty JC, Crump B, et al. Campylobacter pyloridis and associated gastritis: investigator blind, placebo controlled trial of bismuth salicylate and erythromycin ethylsuccinate. $B r$ Med $J$ 1986; 293: 645-9. 